一論 文—

(日本化学会誌, 1989, (12)，p.2039～2045)

(C) 1989 The Chemical Society of Japan

\title{
ミクロ溶媒抽出-黒鉛炉原子吸光法による天然水中の コバルトの定量
}

\author{
(1989 年 5 月 6 日受理)
}

清 水得 $*^{*}$ ・小柳秀 信**・四條好雄・酒 井 馨***

\begin{abstract}
天然水中のコバルトをチオシアン酸錯体としてトリオクチルメチルアンモニウムニクロリド(カプリコ ート）により 1,2-ジクロロベンゼンに抽出し，パイログラファイト処理管を用いる黒鉛炬原子吸光法 により定量する方法について検討した。 $0.1 \mathrm{~mol} / l$ 塩酸酸性とした試料水 $20 \mathrm{~m} l$ を用いて有機相 0.1 $\mathrm{m} l$ に抽出する 200 倍濃縮の場合, $2 \mathrm{~mol} / l$ クエン酸水素ニアンモニウム溶液 $1 \mathrm{~m} l$ と $5 \mathrm{~mol} / l$ チオ シアン酸カリウム溶夜 $0.5 \mathrm{~m} l$ を添加し，有機相中のカプリコート濃度を $0.01 \mathrm{~mol} / l$ として, コバル 卜を抽出した。共存元素の影響は少なく，鉄(III)执よび銅（II）が多量に共存してもクェン酸塩の添加に より影響は抑制された。本法の定量下限 $(10 \sigma)$ は $0.011 \mathrm{ng} / \mathrm{m} l$ であった。標準添加法を用いても， 1 時間以内に抽出操作を終兄て, 黒鉛炉原子吸光測定が可能である。海水扤よび陸水試料の採取地点に打 いて沪過または加熱処理後, 本抽出法を適用した。有機相は分離後車載用冷蔵庫に保存し, 研究室に持 ち帰った後、コバルト濃度をその日のうちに測定した。また，採取後沪過をたは酸を添加して持ち帰っ た試料にも本法を適用し，保存中のコバルト濃度の変化を調べた。
\end{abstract}

\section{1 緒、言}

黒鉛师原子吸光法は，多くの金属元素に対して比較的感度が高 く, 天然水の分析にも広く用いられている。しかし，一部の元素 を除いて，何らかの分離・濃縮操作は欠かせない1)。さらに近年 は，微量元素の溶存状態2汇関する情報も求められており，精度 のよい高感度な分析法が必要となっている。また, 試料の保存法 は分析結果に大きな影響を与えるため, 試料採取後直ちに分析す ることが必要である。現在，原子スペクトル分析装置の小型化に より，野外での測定を可能とするものも開発されている314)が，一 般的ではない。したがって, 少なくとも試料の前処理と分離・濃 縮操作を試料採取地点で行うことが望ましい(5)が，大量の試料， 試薬, 器具などを研究室と同じ样に扱うことは難かしい。

しかしながら黒鉛炉原子吸光法に扰いては，通常 $10 \mu l$ または $20 \mu l$ を黑鉛炻に注入すれば吸光度の測定が可能であり, 測定試 料は $1 \mathrm{~m} l$ 以下でも十分である。そのため著者らは試料や試薬の

宇都宮大学工学部灾用化学科, 321 宇都宮市石井町

** 現在 花王株式会社東京研究所, 131 東京都墨田区文花

*** 現在 日立計測エンジンフリング株式会社, 312 勝田市市 毛

1) R. E. Sturgeon, S. S. Berman, J.A.H. Desaulniers, A.P. Mykytiuk, J.W. McLaren, D.S. Russell, Anal. Chem., 52, 1585(1980).

2) T.M. Florence, Talanta, 29, 345(1982).

3) C. G. Castledine, J.C. Robbins, J. Geochem. Explor., 19, 689(1983).

4) K. Kitagawa, Y. Yasui, Fresenius' Z. Anal. Chem., $321,563(1985)$.

5）赤木 右, 原口紇栗，分析化学，36，688(1987).
使用量を減らし，有機相を $0.1 \mathrm{ml}$ としたミク口溶媒抽出法を考 案し、これまでに海水中のニッケルの，、マンガンクなどを定量し た。しかしこれらはジェチルジオカルバンン酸錯体として抽 出しているため, $\mathrm{pH}$ の調整を必要とした。その後, 塩酸酸性下 でバナジウムのチオシアン酸錯体をトリオクチルメチルアンモニ ウムニクロリド（以下通俗名カプリコートを用いる）とのイオン 対として抽出する方法8)のミク口化を報告したが，本報では，天 然水中では $\mathrm{ng} / \mathrm{m} l$ レベル以下である微量コバルトへの適用を検 討した。

ミクロ溶媒抽出法では，分液漏斗の代わりに遠心沈殿管を用い るので，器具の運搬も容易であり， $\mathrm{pH}$ の調整を必要としなけれ

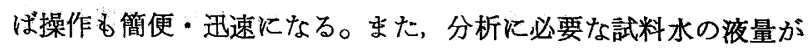
少ないので，沪過などの前処理も容易である。したがって，天然 水中の微量コバルトを試料採取地点で前処理後分離・濃縮し, そ の日のらちに分析することも可能となった。海水と河川水の分析 結果については既に速報した8)。本報では，共存元素の影響など 本法の詳細について報告するとともに，湖水の分析結果，コパル トの溶存状態, 試料の保存などについて報告する。

一般に天然水試料は，採取後直ち汇汇過して $\mathrm{pH} 2$ 以下の酸性 とするか，酸を添加後研究室に持ら帰ってから沪過して，保存ま

6) Y. Shijo, T. Shimizu, K. Sakai, Anal. Sci., 1, 479 (1985).

7) 四條好雄, 渡辺純一郎, 秋山 聡, 清水得夫, 酒井 繁, 分析化学, 36, 59(1987).

8) Y.Shijo, Y.Kimura, T.Shimizu, K. Sakai, Bunseki Kagaku, 32, E 285(1983).

9) T.Shimizu, H. Koyanagi, Y.Shijo, K.Sakai, Chem. Lett., 1986, 319. 
たは分析されている。汇過した試料中の金属イオンは溶存状態に あるものとされ，その全量は加熱または酸化処理によって求める ことになるが, 長時間の酸性保存によって求め得る場合すある10)。 酸化処理をしない陚料の分析值は，例觉ば溶媒抽出法では，遊離 イオン，無機イオン対および有機溶媒に抽出される有機錯体の合

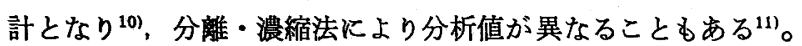
Florence は, 溶存状態を（1）単純な水和金属イオン，(2) 単 純な金属イオン一無機錯体，（3）単純な金属イオンー有機錯体, （4）安定な金属イオン-無機錯体，（5）安定な金属イオン-有機 錯体，（6）無機コロイドに吸着・吸蔵された金属イオン（7） 有機コロイド吸着・吸蔵された金属イオンの 7 通り ${ }^{12}$ ，あるい。 は（8）無機・有機混合コロイド吸着・吸藏された金属イオン を加穴た 8 通り ${ }^{2)}$ 飞分類している。このらち (1)〜 (3) と属す る比較的遊離しやすい状態の金属イオンは，そのまま陽極溶出术 ルタンメトリーで測定でき，(4)〜（7）あるいは（8）の強く結 合した金属イオンは紫外線照射なぞによって测定できるとし，キ レート樹脂法と組み合わせていくつかの金属元素について化学種 の推定も行っている2122\%。

コバルトに関しても，透析，汇過，限外汇過，遠心分離などの 分離操作により粒径や分子量で分画されている ${ }^{13 / \sim 16) 。 S a l b u ~} 5^{15)}$ は, ノルウェ一の地下水㧊よび湖水中の微量元素を, $0.45 \mu \mathrm{m}$ 以 上の粒子状物質, $0.1 \sim 0.45 \mu \mathrm{m}$ 扰よび $0.005 \sim 0.1 \mu \mathrm{m}$ のコロイ ド状物質, $0.005 \mu \mathrm{m}$ 以下の低分子量物質の四つに分類し, 濁度 の高い地下水では粒子状物質飞含まれるコバルトが多く，湖水で は分子量 1 万以下の低分子量物質に含まれるコバルトが多いと報 告した。また, Tanizaki ら ${ }^{16)}$ は多摩川について調へ，上流では粒 子状物質に含まれるコバルトが多く，下流にいくほど低分子量物 質に含まれるコバルトが多いと報告した。Sugimura ら ${ }^{17}$ は，非 極性の合成吸着剂である Amberlite XAD-2 樹脂を用いて遠洋海 水中の有機態金属化合物を分析し，表層付近では溶存コバルトの 大部分が有機態であると報告した。さらに XAD-2 樹脂による濃 縮後, ゲルクロマトクララフ法により分子量分画し, 見かけの分子 量 $1 \times 10^{3} \sim 2 \times 10^{4}$ の間に有機態金属化合物が分配しており, 酸 性下であ安定であるるのが多いと報告した。しかし，無機態の銅 イオンなどる XAD-2 樹脂に吸着するため, 定量的な扱いはでき ないとの報告すある18)。

本報では，試料採取地点で前処理するため，操作が簡便な沪過 と酸性下での加熱処理を組み合わせで゚コバルトの溶存状態を調

10）坪田博行, “海洋無機化学”, 堀部純男編, 2 章, 東京大学 出版会 (1975).

11）清水得夫, 市川兼司, 伊澤雅幸, 四條好婎, 分析化学, 38, 201(1989).

12) T. M. Florence, G.E. Batley, Talanta, 24, 151(1977).

13) P. Benes, E. Steinnes, Water Res., 8, 947(1974).

14) B. Salbu, Mikrochim. Acta, 1981 II, 351.

15) B. Salbu, H. E. Bjornstad, N. S. Lindstrom, E. Lydersen, E. M. Brevik, J. P. Rambaek, P.E. Paus, Talanta, 32, 907(1985).

16) Y. Tanizaki, M. Yamazaki, S. Nagatsuka, Bull. Chem. Soc. Jpn., 58, 907(1985).

17) Y. Sugimura, Y. Suzuki, Y. Miyake, J. Oceanogr. Soc. Jpn., 34，93(1978)；杉村行勇，占九せき，1981， 148.

18) D. J. Mackey, J. Chromatogr., 236, 81(1982).
ベることにした。

\section{2 実験}

\section{1 装置および試薬}

日立製 170-50 型原子吸光光度計汇同社製 GA-2 B 型黒鉛炬を 取り付け，同社製パイログラファイト処理管と浜松ホトニクス製 中空陰極ランプを用いてコバルト濃度を測定した。

遠心沈殿管はパイレックスガラス製のキャップ付き，円錐形の ものを使用した。遠心分離には国産遠心器製手回し沈殷器を使用 した。

試薬の添加と有機相の分取にはエッペンドルフ製マルチペット 4780 を，黒鉛焗への注入には同社製マイクロピペット $(10 \mu l$ 用 $)$ を使用した。

試料水の吸引洰過はミリポア製 $0.45 \mu \mathrm{m}$ メンブランフィルター と東洋沪紙製 VT-500 型減压装置および HP-01 型手動式吸引ポ ンプを用いて行った。

試薬は原子吸光用または特級品を使用した。水は蒸留一脱イオ ン水をさらにミリポフ製 Milli-Q システム绳したものを使用 した。

\section{2 標準操作}

200 倍濃縮の場合, 汇過または後で述べる前处理を行った陚料 水 $20 \mathrm{~m} l$ を $30 \mathrm{~m} l$ 遠心沈股管棌採り，必要飞応じて塩酸を添加し て, $0.1 \mathrm{~mol} / l$ 塩酸酸性とする。これに $2 \mathrm{~mol} / l$ クエン酸水素二ア ンモニウム溶夜 $1 \mathrm{ml}$ と $5 \mathrm{~mol} / l$ チオンアン酸カリウム溶液 0.5 $\mathrm{m} l$ を添加する。さらに $0.01 \mathrm{~mol} / l$ カプリコートー1, 2-ジクロロ ベンゼン溶液 $0.1 \mathrm{~m} l$ を添加し， 5 分間らりまぜる。遠心分離し て有機相を沈降させ，後に述べる器具を用いて有機相をバイアル 瓶に分取する。これから $10 \mu l$ を黑鉛炬飞注入し原子吸光測定す る。試料採取地点で分離・濃縮を行ら場合には，有機相を分取後 車載用冷蔵庫に保存し, 研究室に持ち帰ってから原子吸光測定す る。

\section{3 結果および考察}

\section{1 黒鉛炉原子吸光法の測定条件}

人工海水 ${ }^{20)}$ を用いて 2.2 の標準操作に準じて得た有機相を用 い，黒鉛炉原子吸光法の測定条件を検討した。1，2-ジクロロベン ゼンの沸点は約 $180^{\circ} \mathrm{C}$ であるが，乾燥温度を $170^{\circ} \mathrm{C}$ とすると突 沸したため，乾燥を $160^{\circ} \mathrm{C}, 20$ 秒とし，灰化をランプーモードで 行らことにした。その結果, 突沸はなく、 $1100^{\circ} \mathrm{C}$ まて原子吸光シ グナルは一定であった。したがって，灰化は $700^{\circ} \mathrm{C} ， 40$ 秒とし た。コバルトの原子化は $1200^{\circ} \mathrm{C}$ 付近から始まり, 温度の上昇に ともない原子吸光シグナルも增大したので，原子化は $2800^{\circ} \mathrm{C} ， 5$ 秒とした。

\section{2 溶媒の選択と有機相の分取}

ミクロ溶媒抽出法では有機相が $0.1 \mathrm{ml}$ と少ないため, ベンぜ ンや4-メチル-2-ペンタノンのような比重の小さい溶媒や，比重 が大きくてもクロロホルムのような水に溶解する溶媒を用いる と，有機相の分取が困難になる。またイオン会合亲抽出法の場 合, 溶媒の誘電率が抽出率に関係しているので, 四塩化炭素では

19）清水得夫，川又勇司，木村幸雄，四條好雄，酒井 整，分 析化学, 31, 299(1982).

20）JIS K 2510, 潤滑油さび止め性能試験方法（1980）. 
抽出率が悪い21)。これらのことから，2-クロロトルェン $\left(d_{4}^{20}=\right.$ 1.0825) と 1,2-ジクロロベンゼン $\left(d_{4}^{20}=1.306\right)$ を選んだ。塩分 濃度が約 $35 \%$ である人工海水の比重は約 1.028 であるが, 試楽 添加後には約 1.038 となるので, 前者は海水よりも河川水などの 比重の小さい試料水に, 後者は海水などの比重の大きな試料水に も適している。したがって, 本法では主に 1,2-ジクロロベンゼン を用いることにした。

ミクロ溶媒抽出法では溶媒が少ないため，抽出後の有機相は分 散し, 表面に浮いたり, 壁面に付着するので, 遠心分離を行って 有機相を沈降させる必要がある。手回し沈殿器は $10 \mathrm{ml}$ または $15 \mathrm{ml}$ の遠心沈殿管用であるので, $30 \mathrm{ml}$ または $40 \mathrm{ml}$ のものを 用いるためにスイング型のローターを改良した。遠心沈殿管の肩 とキャップの間の隙間の径に合わせたリングを針金でつくり, 回 転に応じて遠心沈股管がスイングするよらに，金具でローターに 取り付けた。遠心沈殿管のキャップをはずしてリングに通し，再 びキャップをはめて固定してから，遠心分離を行った。

有機相の分取には, 既報阮ではマイクロシリンジにガラス管と テフロンキャピラリーを取り付けたものを使用していたが，本法 では試料採取地点で操作するため,さらに簡便な器具が必要とな った。マルチペット 4780 は野外での試薬の分注に便利であり, 使用済みのチップの交換も容易であるが，チップのシリンジ部分 が約 $77 \mathrm{~mm}$ と短いため $30 \mathrm{ml}$ 遠心沈殿管の底部 (約 $104 \mathrm{~mm}$ ) に届かない。そのため, 先端にマイクロピペット用の 2 種類のチ ップを取り付け全長を約 $113 \mathrm{~mm}$ と長くした。これにより，40 $\mathrm{m} l$ 遠心沈殿管を用いても有機相を分取できるよらになった。ま た，レバーを操作しなければ液を吸引しないので, 水相は混入し ない。

分取後の有機相から $10 \mu l$ を黒鉛炬に注入して原子吸光シグナ ルを 3 回測定する場合には有機相の液量は $50 \mu l$ でも十分である が, 野外で迅速に操作しなければならないので, 本法では有機相 を分取しやすい $0.1 \mathrm{ml}$ とした。

\section{3 抽出条件之回収率}

人工海水を用いて 2.2 の標準操作に準じ, 水相中の塩酸濃度 を変化させてコバルトの抽出におよぼす影響を調べた結果を図 1 に示す。松尾ら ${ }^{22)} は$, 親水性第四級アンモニウム塩であるテトラ デシルジメチルベンジルフンモニウムニクロリト(ゼフィラミン)/ クロロホルム系で, コバルトのチオシアン酸䤮体を $4 \mathrm{~mol} / l$ 塩酸 酸性から $\mathrm{pH} 8$ の範围で定量的に抽出している。親油性第四級ア ンモニウム塩であるカプリコートでは，抽出範囲が約 $0.04 \mathrm{~mol} / \mathrm{l}$ から $0.5 \mathrm{~mol} / l$ 塩酸酸性と狭くなっている。しかし, 通常の試料 水の保存と同じ条件である, $0.1 \mathrm{~mol} / l$ 塩酸酸性下で抽出を行え るので, 実用上は極めて好都合である。

チオシフン酸-コバルト錯陰イオンの生成ならびにカプリコー トとのイオン会合抽出に拉よぼすチオシアン酸カリウム濃度の影 響について調べた。その結果, 水相として水を用いた場合よりも 人工海水を用いた場合の方が, 高いチオシアン酸䟴度を必要とし た。したがって，チオシアン酸カリウムをコバルトに対してモル 比で約 $7 \times 10^{7}$ 倍, すなわち $5 \mathrm{~mol} / l$ 溶液を $0.5 \mathrm{ml}$ 添加して, 水 相中の濃度を約 $0.12 \mathrm{~mol} / l$ にすることにした。

2.2 の標準操作においてカプリコートの濃度のみを变えて, コ

21）酒井忠雄，本水昌二，ぶんせき，1989，15.

22）松尾 博, 熊丸尚宏, 原 茂樹, 分析化学, 29, 337(1980).

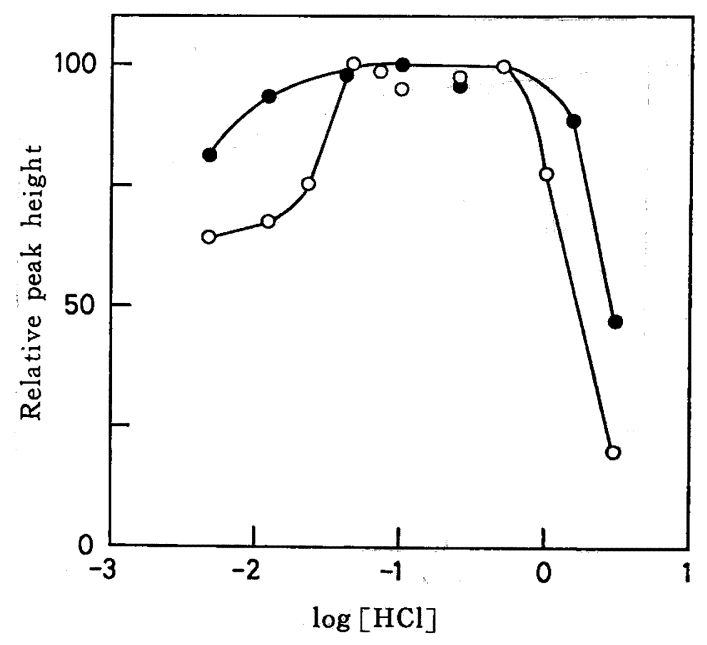

Fig. 1 Effect of hydrochloric acid concentration on the extraction of cobalt

O : 1,2-Dichlorobenzene, : 2-Chlorotoluene, Cobalt : $2 \mathrm{ng}$, Aiqueous phase : Artificial sea water $20 \mathrm{~m} l$, Organic phase : $0.01 \mathrm{M}$ Capriquat $0.1 \mathrm{~m} l$

バルトの抽出に拈よぼす影響について調べた。その結果，我相と して人工海水を用いた場合も，カプリコートをコバルトに対して モル比で約 $3 \times 10^{6}$ 倍, 寸なわち有機相中の䟴度を $5 \times 10^{-3} \mathrm{~mol} / l$ 以上に保てば, 最大一定の原子吸光シグナルが得られることがわ かった。したがって，有機相中のカプリコート濃度を $0.01 \mathrm{~mol} / l$ にすることにした。

ふりまぜ時間がコバルトの抽出におよぼす影響について調べた ところ，1分以上手でふりまぜることにより原子吸光シグナルは 最大一定となったので，以後ふりなせ時間は 5 分間とした。

2.2 の標準操作において，水相中のコバルトの絶対量，および チオシアン酸カリウムとクエン酸水素二アンモニウムの濃度を一 定に保ち，人工海水の容量を種々変化させて， $V_{\mathrm{aq}} / V_{\text {org }}$ と原子 吸光シグナルの関係を調べた。図 2 に示したように, 容量比すな わち濃縮倍率が増加するにつれて原子吸光シグナルは徐々に低下 しているが, 300 倍でもコバルトの定量は可能である。しかし， それ以上になると有機相の分離が悪くなり，分取が困難になっ た。松尾ら ${ }^{221}$ は $V_{\text {aq }} / V_{\text {org }}$ が 15 以上になると抽出率が低下する ため, 試薬濃度を 2 倍にすることにより 50 倍濃縮を達成してい る。しかし,クロロホルムの水への溶解度は 1,2-ジクロロベンゼ ンよりも大きいため, 100 倍以上の濃縮は望めない。1,2-ジクロ ロベンゼンで飽和させた人工海水と，そのままのすのを用いて 2.2 の標準操作にしたがってコバルトを抽出したが，原子吸光シ グナルには影響がなく, 溶媒の水への溶解は無視できる。また, バイアル瓶に分取した有機相の保存は, 室温では原子吸光シグナ ルが変動したが，冷蔵庫中であれば 72 時間後でも変化はなかっ た。

本法では有機相を黒鉛炉原子吸光測定しているので，標準溶液 と比較して回収率を求めることはできない。したがって，有機相 を硝酸を用いて逆抽出する方法）（以下逆抽出法と略記する）と， 有機相をロータリーエバポレーターを用いて蒸発乾固後残留物を 硝酸 ${ }^{19)}$ とテトラヒドロフランに溶解する方法（以下 RE 法と略記 


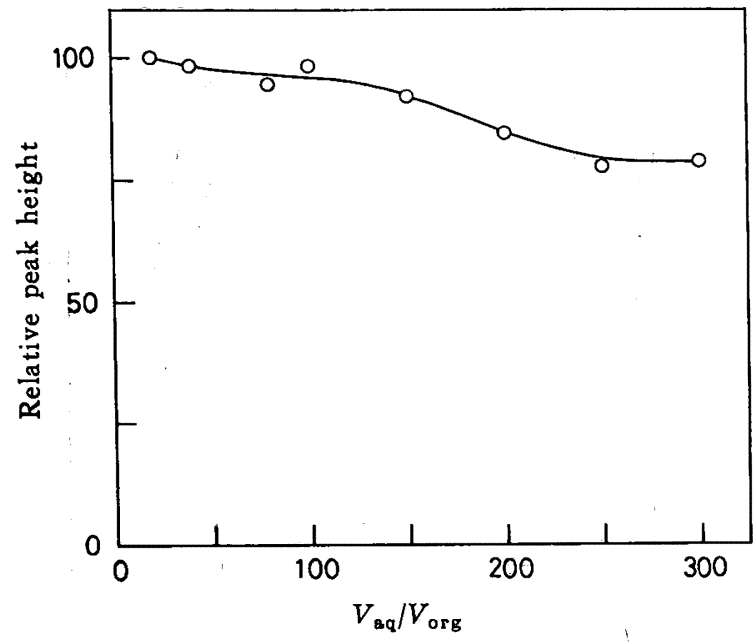

Fig. 2 Effect of aqueous/organic phase volume ratio on the extraction of cobalt

Cobalt: $2 \mathrm{ng}$, Aqueous phase : Artificial seawater 2 $30 \mathrm{ml}$, Organic phase : $0.01 \mathrm{M}$ Capriquat in 1,2dichlorobenzene $0.1 \mathrm{~m} l$

する）により求めることにした。人工海水 $400 \mathrm{~m} l$ と有機相 $2 \mathrm{~m} l$ を用いて 2.2 の標準操作に準じてコバルトを 200 倍濃綟し，有 機相のらち正確に $1 \mathrm{~m} l$ を分取して逆抽出法または $\mathrm{RE}$ 法を行っ た。試薬ブランクも同様に操作した後二分し，一方にコバルトを 添加した。原子吸光シクナルを比較して回収率 $(n=3)$ を求めた ところ，逆相出法により $82.8 \pm 2.8 \% ， \mathrm{RE}$ 法により $81.5 \pm$ $1.5 \%$ であった。四2は20 倍滥縮における原子吸光シグナルを 100 とした相対ピーク高さで表しており，これらのことから，人 工海水を用いて 200 倍濃縮した場合の抽出率は約 $80 \%$ であると 思われる。

\section{4 共存イオンの影響}

天然水中のコバルトの濃度は通常 $\mathrm{ng} / \mathrm{m} l$ 以下之低いため, コ ハルトと共存しやすい元素，チオシフン酸錯陰イオンを生成する 金属イオンについて，それらがコバルトの溶媒抽出ならびに原子 吸光測定におよばす影響について調へた。人工海水を用いたとき の結果を表 1 亿示す。9 種の元素について海水中の存在予想量101 を基に， 1 倍量，10 倍量，100 倍量共存させたところ，クエン酸 水素二アンモニウムを添加しないと，10 倍量では正の干渉が， 100 倍量では原子吸光シグナルの変動がみられた。しかし，クエ ン酸水素ニアンモニウムを添加すると，100 倍量でもほとんど影 響はなかった。

クエン酸塩は中性からアルカリ性にかけて，多価金属イオンの マスキンク剤として使われており、コバルトもモル比で 1:1の 場合, $\mathrm{pH} 6$ 付近では $[\mathrm{Co}(\mathrm{HcitH})]^{-}$が大部分を占めるが, $\mathrm{pH} 1$ 以下では汪とんど錯体を生成しない23)。表 2 亿，鉄(III）または銅 （II）をコバルトの 5000 倍量共存させた場合の種々のマスキング 凧の影䇾を示す。これから EDTA がマスキング剤として優れて いることがわかる。チオ尿素は銅(II) 飞対してはマスキング効 果がある。酒石酸の添加に上り原子吸光シグナルは增大して括

23）藤井 知，覚野宏，杉江他兽宏，坂本千秋，日化，1985， 1635.
Table 1 Effect of diverse ions on the determination of cobalt

Ions Concentration, $\mu \mathrm{g} / l$

$\begin{array}{llcrr} & & & & \\ \operatorname{nyy}(\text { IV) } & 0 & 1 & 10 & 100 \\ \mathrm{~V}(\mathrm{~V}) & 0 & 1.9 & 19 & 190 \\ \mathrm{Cr} \text { (III) } & 0 & 1 & 10 & 100 \\ \mathrm{Mn} \text { (II) } & 0 & 0.4 & 4 & 40 \\ \mathrm{Fe} \text { (II) } & 0 & 3.4 & 34 & 340 \\ \mathrm{Ni} \text { (II) } & 0 & 2 & 20 & 200 \\ \mathrm{Cu} \text { (II) } & 0 & 0.9 & 9 & 90 \\ \mathrm{Mo} \text { (II) } & 0 & 10 & 100 & 1000 \\ \mathrm{Cd} \text { (II) } & 0 & 0.11 & 1.1 & 11\end{array}$

Relative peak height

$\begin{array}{llllr}\text { a) } & 100 & 101.7 & 109.6 & 99.1 \\ \text { b) } & 100 & 100.3 & 100.5 & 101.5\end{array}$

Cobalt : $0.1 \mu \mathrm{g} / l, V_{\text {aq }} / V_{\text {org }}: 20 \mathrm{~m} l / 0.1 \mathrm{~m} l$ Artificial sea water was used.

a) In the absence of diammonium hydrogencitrate.

b) In the presence of diammonium hydrogencitrate.

Table 2 Effect masking agents on the determination of cobalt

Relative peak height

\begin{tabular}{lccc}
$\begin{array}{c}\text { Masking agents } \\
(\mathrm{mol} / l)\end{array}$ & None & $\begin{array}{c}\mathrm{Fe}(\mathrm{II}) \\
10 \mu \mathrm{g}\end{array}$ & $\begin{array}{c}\mathrm{Cu}(\mathrm{II}) \\
10 \mu \mathrm{g}\end{array}$ \\
\hline None & 100.0 & 160.1 & 123.8 \\
Diammonium hydro- & 107.2 & 105.2 & 116.4 \\
$\quad$ gencitrate $(0.09)$ & 101.0 & 101.0 & 103.4 \\
EDTA $\cdot 2 \mathrm{NH}_{4}(0.005)$ & 101.1 & 97.3 & 107.0 \\
EDTA·2 Na $(0.005)$ & 100.7 & 140.2 & 101.3 \\
Thiourea $(0.09)$ & 118.4 & 164.6 & 128.4 \\
Tartaric acid $(0.024)$ & & \\
Cobalt $: 2 \mathrm{ng}, V_{\mathrm{aq}} / V_{\text {org }}: 20 \mathrm{~m} l / 0.1 \mathrm{ml}$. & &
\end{tabular}

ク、コバルトの抽出に対して何らかの影響を与充たるのと思われ るが，マスキング効果はない。しかし，クエン酸水素ニアンモニ ウムの場合む，原子吸光シグナルがわずかではあるが增大してお り，マスキング効果す EDTA ととれはど違いはない。したがっ て, 本法では， $2 \mathrm{~mol} / l$ クェン酸水素三フンモニウム溶夜を $1 \mathrm{ml}$ 添加して，水相中の濃度を約 $0.09 \mathrm{~mol} / l$ とすることとした。

\section{5 検出限界と精度}

本法 (200 倍濃縮) の検出限界 $(3 \sigma)$ は $0.003 \mathrm{ng} / \mathrm{ml}$ であり, 定量下限 $(10 \sigma)$ は $0.011 \mathrm{ng} / \mathrm{ml}$ であった。コバルト濃度を $2 \mathrm{ng} /$ $20 \mathrm{~m} l$-とした人工海水を用いて 10 回のくり返し実験を行ったと ころ，分析精度は，相対標準偏差で $1.1 \%$ であった。

\section{4 実際試料への適用}

\section{1 試料水の加熱方法}

溶存状態にある金属イオンの全量を求める場合，JIS ${ }^{24)}$ では各 種の酸を加えて加熱処理する方法が 4 種類規定されている。しか し，硝酸を用いるとチオンフン酸と反応するため, $0.1 \mathrm{~mol} / l$ 程度 でも有機相が着色し, $0.6 \mathrm{~mol} / l$ では水相も着色し有機相が黄濁 した。また，過塩素酸はカプリコートとイオン対を生成するた め, $0.2 \mathrm{~mol} / l$ 付近から白色沈殿が認められ, $0.4 \mathrm{~mol} / l$ では有機

24） JIS K 0101，工業用水試験方法（1986)；JIS K 0102，工 場排水試験方法（1986）. 
Table 3 Comparison of the two heating treatment methods

\begin{tabular}{lll}
\multirow{2}{*}{ Samples } & \multicolumn{2}{c}{ Cobalt found, $\mu \mathrm{g} / l$} \\
\cline { 2 - 3 } & \multicolumn{2}{c}{ Method } \\
\hline Lake water (Yunoko) & & $\mathrm{H} 2$ \\
\hline Yumoto & 0.039 & 0.038 \\
$\quad$ Yudaki-ue & 0.024 & 0.024 \\
River water (Watarase) & & \\
$\quad$ Ashio dam & 0.163 & 0.197 \\
$\quad$ Sunahata & 0.165 & 0.170
\end{tabular}

Method $\mathrm{H} 1$ : One $\mathrm{ml}$ of conc. $\mathrm{HCl}$ was added to $100 \mathrm{ml}$ of sample, and boiled for an hour.

Method $\mathrm{H} 2$ : Five $\mathrm{m} l$ of conc. $\mathrm{HCl}$ was added to $100 \mathrm{~m} l$ of sample, and evaporated to ca. $15 \mathrm{ml}$.

相が分離でさなくなった。したがって，塩酸を用いて加熱処理す る方法を比較した。試料水 $100 \mathrm{~m} l$ に塩酸 $1 \mathrm{~m} l$ を加えて水浴で 1 時間煮沸し，放冷後沪過してふたたび $100 \mathrm{ml}$ に定容とする $\mathrm{H} 1$ 法と, 試料水 $100 \mathrm{~m} l$ に塩酸 $5 \mathrm{~m} l$ を加兑て液量が約 $15 \mathrm{~m} l$ にな るまで加熱蒸発し，放冷後沪過してふたたび $100 \mathrm{ml}$ に定容とす る $\mathrm{H} 2$ 法の二つである。河川水中の有機物の濃度は溶存態, 粒子 状ともに海水中よりも高い25) といわれているので，湖水と河川水 を用いて比較した。表 $3 に$ 示したよらに, 分析徝はほぼ一致し た。足尾砂防ダムの $\mathrm{H} 2$ 法の值が高いのは, 土砂で濁っていたの
で，これからの溶出分が $\mathrm{H} 1$ 法より多かったためと思われる。し かし, 試料採取地点で前処理するため, また抽出時の塩酸湦度を $0.1 \mathrm{~mol} / l$ とするため, 加熱処理には簡便な $\mathrm{H} 1$ 法を用いること にした。

\section{2 天然水中のコバルトの溶存状態}

コバルトの溶存状態を調べるために, 試料採取地点で以下に示 す三つの前処理 ( $\mathrm{A} \sim \mathrm{C}$ 法) を行い, 2.2 の標準操作にしたがっ て標準添加法によりコバルトを分離・濃縮した。黒鉛炬原子吸光 測定は，研究室に持ち帰ってからその日のうちに行った。

$\mathrm{A}$ 法 : 採取した試料水 $100 \mathrm{ml}$ を $200 \mathrm{ml}$ コニカルビーカーに分 取し, 塩酸 $1 \mathrm{~m} l$ を加兄て, 水浴で 1 時間煮沸する。放冾後汇過 し, 沪液を $100 \mathrm{ml}$ メスフラスコに採り，定容にする。

$\mathrm{B}$ 法：採取した試料水を沪過し，そのうち $100 \mathrm{ml}$ を $200 \mathrm{ml}$ ュ ニカルビーカーに分取し，塩酸 $1 \mathrm{ml}$ を加えて，水浴で 1 時間煮 沸する。放冷後, $100 \mathrm{ml}$ メスフラスコに移し, 定容にする。

C 法 : 採取した試料水を沪過し，抽出時に塩酸を加える。 さらに以下に示す二つの方法 (D, E 法) で試料水を保存し, 研 究室に怙いて，2.2 の標準操作にしたがって標準添加法によりコ バルトを分析した。

$\mathrm{D}$ 法：採取した試料水を污過して $1 l$ ガラス瓶に採り， $100 \mathrm{ml}$ につき塩酸 $1 \mathrm{~m} l$ を加えて, 車載用冷蔵庫に保存する。

$\mathrm{E}$ 法：採取した試料水を沪過せずに，10lポリェチレン容器に 採り， $1 l$ につき塩酸 $10 \mathrm{~m} l$ を加えて，室温で保存する。

Table 4 Comparison of the analytical results for natural waters by the five pretreatment methods

\begin{tabular}{|c|c|c|c|c|c|}
\hline \multirow{3}{*}{ Samples ${ }^{a)}$} & \multicolumn{5}{|c|}{ Cobalt found, $\mu \mathrm{g} / l$} \\
\hline & \multicolumn{5}{|c|}{ Method } \\
\hline & A & B & $\mathrm{C}$ & D & $\mathbf{E}$ \\
\hline \multicolumn{6}{|l|}{ Seawater '85.9.6 } \\
\hline Hitachi & 0.110 & 0.043 & 0.052 & $0.047 \pm 0.004^{\ell}$ & $0.116 \pm 0.018$ \\
\hline Isozaki & 0.043 & 0.021 & 0.023 & $0.023 \pm 0.002$ & $0.028 \pm 0.003$ \\
\hline Watarase river & & & & & \\
\hline Ashio dam & 0.222 & 0.017 & 0.006 & $0.008 \pm 0.003$ & $0.131 \pm 0.003$ \\
\hline Honzan mine & 1. 17 & 1.25 & 1. 16 & $1.23 \pm 0.09$ & $1.08 \pm 0.04$ \\
\hline Lake Chuzenji '85.10.18 & & & & & \\
\hline Ohjiri & 0.023 & 0.011 & 0.003 & $0.004,0.003$ & $0.005,0.005$ \\
\hline
\end{tabular}

a) 200 fold preconcentration, except Honzan mine carried out by 20 or 50 fold.

b) Mean \pm standard deviation $(n=3)$.

Method A: One $\mathrm{m} l$ of conc. $\mathrm{HCl}$ was added to $100 \mathrm{~m} l$ of collected sample, boiled for an hour, and filtered through $0.45 \mu \mathrm{m}$ filter.

Method B: One $\mathrm{m} l$ of conc. $\mathrm{HCl}$ was added to $100 \mathrm{~m} l$ of filtered sample, and boiled for an hour.

Method C : Collected sample was filtered.

In methods $\mathrm{A}-\mathrm{C}$, micro solvent extraction was done at the sampling points. The organic phases were stored in a refrigerator, and determined in the laboratory within a day.

Method D: Ten $\mathrm{ml}$ of conc. $\mathrm{HCl}$ was added to $1000 \mathrm{ml}$ of filtered sample, and stored in a refrigerator. Micro solvent extraction was done in the laboratory within a week for sea and river waters, ten days for lake water.

Method $\mathrm{E}:$ One hundred $\mathrm{m} l$ of conc. $\mathrm{HCl}$ was added to $10 l$ of collected sample, and stored at room temperature. Filtration and micro solvent extraction were done in the laboratory after two weeks for river waters, three weeks for seawaters, and five months for lake water.

25）日本化学会編, “トレース・キャラクタリゼーション, 化学総説 No. 28”, 学会出版センター（1980） p. 109. 
A 法と B 法の差が懸濁物質中の加熱処理により抽出できるコバ ルトの浧度であり、B法とC法の差が溶存状態にあるコバルトの らち加熱処理により抽出できる化学種と考えられる。また， C法 により容易に抽出される化学種は, Florence ${ }^{2)}$ の分類にしたがう と, （1）に属するコバルトと，(2)〜（8）に属するコバルトの らちチオシアン酸と容易に反応するか，酸の添加で容易に遊離す るコバルトと考えられる。

これら 5 通り（A〜E法）の前処理を行った天然水の分析結果 を表 4 に示す。本山坑の試料水は 20 倍または 50 倍濃縮とし た。湖水の場合，有機相がいくつかの粒状に分かれ，特にE法で は細かくなり分取できなかった。界面活性剂など共存成分の影響 と考え種々検討したが，原因を明らかにできなかった。加熱処理 を行らか，長期間保存すると有機相を分取できるようになったの で，E法の值は約 5 か月後の分析結果である。懸濁物質中のコバ ルトと溶存状態にあるコバルトの濃度は, 河川水を除き, 同程度 であった。海水では，B法，C法とD法の值にほとんど差がない ことから，容存状態にあるコバルトはすべて容易に抽出される化 学種であったと考えられる。したがって, 沿岸の表面水ではフ

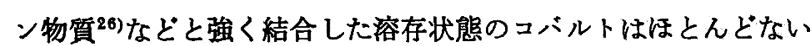
と思われる。また A法と E法の結果から，工業港である日立の場 合, 愁濁物質中のコバルトは酸の添加により容易に溶出したるの と考えられ，漁港である磯崎との違いが大きい。

河川水では，本山坑跡のコバルト濃度は高く，ほとんどが溶存 状態にあって容易に抽出される化学種であっだ。足尾砂防ダムで は懸濁物質中のコバルト濃度が高く、酸の添加によってはあまり 溶出しない。中禅寺湖大尻の湖水では, $\mathrm{A}$ 法と B 法以外は定量下 限以下であったが，足尾砂防ダムと同様に，溶存状態にあるコバ ルトのらちで容易に抽出される化学種の割合は小さいと思われ る。

表 5 に，海水と河川水中のコバルト濃度の保存による变化を示 す。ここでA〜C法のらち，表 4 から引用した值以外は，未沪 過・酸無添加の試料水を冷蔵庫に保存し，よくふり混ぜた後それ ぞれの前処理を行ったるのである。これから，溶存状態にある微 量コハルトの濃度は吸着などにより変化しやすいが, 採取後速や かに沪過して酸を添加すれば，少なくとも6か月は保存できるこ とがわかる。

また, 1986 年 11 月から 12 月にかけて噴火した伊豆大島の海 水を，翌年の 1 月 1 日に採取して持ら帰り，塩酸を添加して数日 後に汇過して分析したところ, 変色海水が観察された筆島ではコ バルト濐度が $0.259 \pm 0.007 \mu \mathrm{g} / l(n=3)$ と, 岡田と波浮のそれぞ

26）紊藤喜二，ふんんせき，1980，816.
Table 5 Changes of cobalt contents in natural waters during the storage

\begin{tabular}{|c|c|c|c|c|c|}
\hline \multirow{3}{*}{ Sample } & \multirow{3}{*}{ Method $a)$} & \multicolumn{4}{|c|}{ Cobalt found, $\mu \mathrm{g} / l$} \\
\hline & & \multicolumn{4}{|c|}{ Storage time } \\
\hline & & $\begin{array}{c}\text { Within } 7 \\
\text { or } \\
10 \text { days }^{b)}\end{array}$ & $\begin{array}{l}2 \text { or } 3 \\
\text { weeks }\end{array}$ & $\begin{array}{c}c a .3 \\
\text { months }\end{array}$ & $\begin{array}{l}\text { ca. } 6 \\
\text { months }\end{array}$ \\
\hline \multirow{5}{*}{ Hitachi } & A & 0.110 & - & 0.093 & 0.065 \\
\hline & B & 0.043 & - & 0.017 & - \\
\hline & $\mathrm{C}$ & 0.052 & - & 0.008 & 0.004 \\
\hline & $\mathrm{D}$ & 0.047 & - & 0.046 & 0.043 \\
\hline & $\mathrm{E}$ & - & 0.115 & - & 0.110 \\
\hline \multirow{5}{*}{ Isozaki } & A & 0.043 & - & 0.022 & 0.020 \\
\hline & B & 0.021 & - & 0.010 & - \\
\hline & $\mathrm{C}$ & 0.023 & - & 0.005 & $<0.003$ \\
\hline & $\mathrm{D}$ & 0.023 & - & 0.021 & 0.023 \\
\hline & $\mathrm{E}$ & - & 0.025 & 0.025 & 0.028 \\
\hline \multirow{5}{*}{$\begin{array}{l}\text { Ashio } \\
\text { dam }\end{array}$} & A & 0.222 & - & 0.230 & 一 \\
\hline & B & 0.017 & - & 0.015 & - \\
\hline & $\mathrm{C}$ & 0.006 & - & 0.003 & $<0.003$ \\
\hline & $\mathrm{D}$ & 0.008 & - & 0.012 & 0.009 \\
\hline & $\mathrm{E}$ & 一 & 0.132 & - & 0.138 \\
\hline \multirow{5}{*}{$\begin{array}{l}\text { Honzan } \\
\text { mine }\end{array}$} & A & 1. 16 & - & 0.97 & - \\
\hline & B & 1.25 & - & 1.02 & - \\
\hline & $\mathrm{C}$ & 1.17 & - & 1.03 & 1.09 \\
\hline & $\mathrm{D}$ & 1. 23 & - & 1.02 & 1.09 \\
\hline & $\mathrm{E}$ & - & 1. 10 & 0.95 & 1.00 \\
\hline
\end{tabular}

a) Procedures of five pretreatment methods were shown in Table 4. Unfiltered and unacidified samples stored in a refrigerator were used for Methods A-C, except for $b$ )

b) These values were quoted from Table 4 .

れ $0.033 \pm 0.001 \mu \mathrm{g} / l(n=3), 0.019 \pm 0.002 \mu \mathrm{g} / l(n=3)$ に比較 して高かった。

\section{5 結言}

以上，チオシアン酸-カプリコート系イオン対抽出を利用する ことにより，天然水中の微量コバルトを分離・濃縮し，精度よく 高感度に黒鉛炉原子吸光定量することが可能であった。本法は, 少量の試料水で分析できるので，その採取と保存も容易であり， 遠洋水などの貴重な試料水の分析にも適している。本法は, 遠心 沈殿管を用いるため器具などの運搬も容易であり, また $\mathrm{pH}$ の調 整を必要とせず，操作も簡便・迅速であるため，溶存状態の分析 に不可欠な試料採取地点での操作が可能である。 


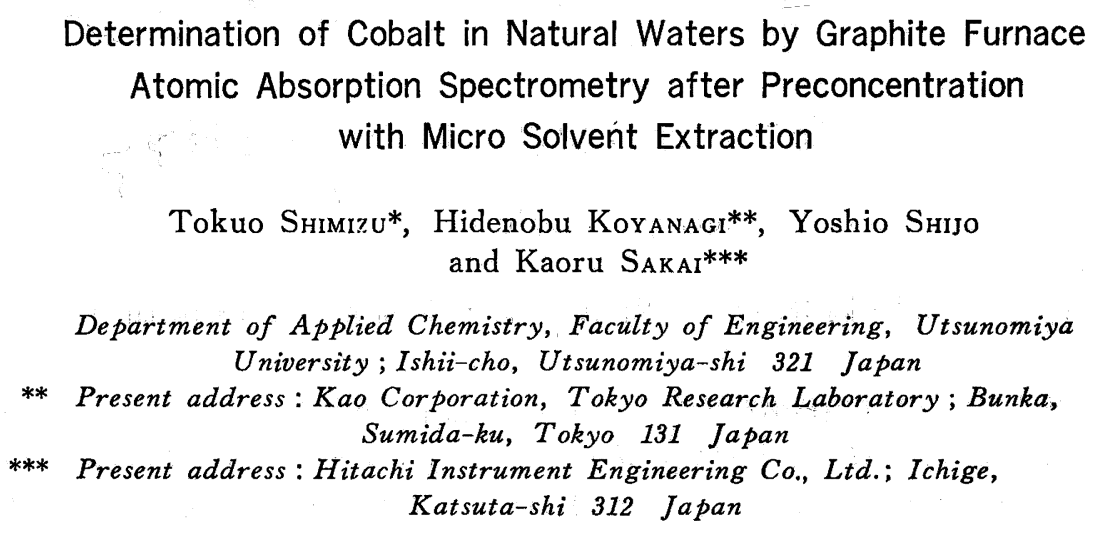

A simple and rapid preconcentration method for the determination of cobalt in natural waters is described. The proposed method is based on the extraction with $0.1 \mathrm{ml}$ of solvent in a centrifuge tube, and a preconcentration factor of 200 times is obtainable using $20 \mathrm{~m} l$ of sample. The optimum preconcentration conditions were examined. The surface water samples, seawater, river water and lake water, were pretreated by filtering or heating under the acidity of $0.1 \mathrm{~mol} / l$ hydrochloric acid. The trace amount of cobalt in sample solution was extracted as thiocyanato complex with trioctylmethylammonium chloride in 1,2-dichlorobenzene, and determined by graphite furnace atomic absorption spectrometry using a pyrolytic graphite coated tube. At the sampling points, three methods of pretreatment and the micro solvent extraction were performed. The organic phases separated were stored in a refrigerator, and determined in the laboratory within a day (Methods A to C). And further, the stored samples, filtered/acidified and unifiltered/acidified, were supplied to the proposed method in the laboratory (Methods D and E). The untreated samples were also stored, and determined. The results show that the contents of labile or extractable species in the filtered sample do not vary so much by acidification and during the storage in a refrigerator. In the case of seashore waters, the dissolved or filterable cobalt is seemed to be almost labile or extractable. In the case of land waters, the cobalt contents in lake water are seemed to be lower than those in river water. The lower limit of determination $(10 \sigma)$ was found to be $0.011 \mathrm{ng} / \mathrm{m} l$ of cobalt in the initial solution. The relative standard deviation was $1.1 \%$ for $0.1 \mathrm{ng} / \mathrm{m} l$ of cobalt in artificial sea water $(n=10)$. Interferences of many metal ions can be effectively reduced by masking with diammonium hydrogencitrate. 